\title{
CONCEPT OF ISLAMIC EDUCATION IN THE QUR'AN
}

\section{Muh. Haris Zubaidillah}

Email: hariszub@gmail.com

\begin{abstract}
Education is to develop the development of physical and spiritual potential encompassing the full potential of students, both psychomotoric, cognitive potential, and their affective potential for the realization of human beings who have the main personality in terms of religion is Insan Kamil and to be a servant of Allah SWT who always close to Him. For human education is an important effort to instill and actualize Islamic values in real life through faithful and pious Muslims who, according to the dignity and degree of humanity as a caliph on earth. The concept of education in Islam which refers to the teachings of the Qur'an, there are three basic concepts: cultivation of faith and aqidah, educational pillars and social ethics as revealed from Lukman's advice to his son.
\end{abstract}

Keywords: concept, islamic education, quran

\section{A. Prologue}

Alquran is the words of Allah which is then used as the way of life of the Muslims ${ }^{1}$ that there is no doubt in it. In it contains the basic principles (basic principles) concerning all aspects of human life which can then be developed in

${ }^{1}$ Muh Haris Zubaidillah, 'HAQIQAH DAN MAJAZ DALAM ALQURAN', 1, accessed 19 July 2018, https://doi.org/10.31227/osf.io/fzatu. 
accordance with the rationality of each nation and at any time and present functionally solving humanitarian problems. One of the worst problems of people's discussions is educational problems.

In the Qur'an itself it has signaled that educational issues are very important, if the Qur'an is studied more deeply then we will find some educational concepts, which then we can inspire to develop in order to build quality education. ${ }^{2}$ There are several indications found in the Qur'an relating to education, among others; The cultivation of Faith and the Faith, Respect human reason, scientific guidance, human nature, use of stories (story) for educational purposes and nurturing social needs of society.

To study the aspects of education in the Qur'an then this paper is deliberately made. In this paper the author only explains the understanding of education, the urgency of education in Islam and the concept of education according to Al Quran and Al Hadits.

\section{B. Defining Education}

The term education can be found in the Qur'an with the terms 'at-Tarbiyah', 'at-Ta'lim', and 'at-Tadhib', but we find more with the term 'rabbi', said at-Tarbiyah is masdar from fi'il madhi 'rabba', which has the same meaning as the word ' $r a b b$ ' which means the name of Allah. In the Qur'an no word found at 'at-Tarbiyah', but there is a term similar to that of; ar-rabb,

${ }^{2}$ Muh Haris Zubaidillah, 'EPISTEMOLOGICAL VIEWS OF ISLAMIC EDUCATION PHILOSOPHY AS A ISLAMIC EDUCATION BASIS.', Al Qalam: Jurnal Ilmiah Keagamaan Dan Kemasyarakatan 1, no. 1 (2018): 5. 
murabbi, rabbiyun, rabbani. It is better in the hadith to use the term rabbani. All the phonemes have different meaning connotations.

Education is the meaning of the word 'Tarbiyah' the word comes from three words; Growing Rabaa-yarbu, growing, and 'Rabbiya-yarbaa' means being big, as well as 'rabba-yarubbu' which means improving, controlling, guiding, maintaining, maintaining.

So the arab rabbis have a broad meaning; have, control, organize, maintain, feed, grow, develop and even educate.

The understanding of education according to Marimba quoted by Prof. Dr. Ahmad Tafsir states that education is consciously guided or educated by educators on the physical and spiritual development of the protagonist towards the formation of a major personality. From the Marimba's opinion, the writer concludes that education is to grow the physical and spiritual potential of enabling the full potential of a child, both psychomotoric, cognitive, and affective potential for the realization of human beings who have the main personality in his religious terms are Insan Kamil and being a servant of Allah SWT who always approaches Him. ${ }^{3}$

\section{Urgency of Education in Islam}

The first human duty is to be a devout servant of God, as the word of God in the Qur'an of Surat Adz-Dzariyat 56, which means: "And I did not create jinn and men but to serve

3 Muh Haris Zubaidillah, 'NILAI-NILAI PENDIDIKAN ADVERSITY QUOTIENT PADA CERITA NABI MÛSÂ DALAM ALQURAN', Al Qalam: Jurnal Ilmiah Keagamaan Dan Kemasyarakatan 11, no. 24 (2017): h. 4. 
Me." Humans are commanded to worship only to Allah, for there is no god but Him. "Worship Allah, there is no god besides Him" (Al-A'raaf: 59).

In order to fulfill his duty, Allah has equiped it with knowledge, as in His word "And He teaches Adam the names (objects) entirely ..." (Al-Baqarah: 31). This is the forerunner of the science taught to the first man from the Master of Science. In addition to the Prophet Adam AS, Allah SWT also provides wisdom (prophethood, perfection of knowledge and deeds of deeds of charity) to the prophets and apostles. To some of the apostles also, God sent down the holy book as a source of knowledge. The Word of Allah: "As We have sent unto you a messenger among you, to recite unto you Our revelations and purify you, and to teach you the Book and the Wisdom, and to teach you what ye know not. "(QS Al Baqarah: 151). In some of his verses also, God gives a special place to Muslims who have knowledge.

As the Owner, God's knowledge is vast, including earth and sky. Some of his sciences are revealed through his apostles in the form of qauliyyah verses (eg: Qur'an, Hadith). On the other hand, Allah describes it in the form of kauniyyah verses (ie natural occurrence, cause of disaster, origin of human life, etc.). So the essence of knowledge is that which relies on the prophecy, and what is beneficial to it is what the Messenger brought. So something that we can say is the right curiosity and accurate research. Thus, there are two types of science; religious and worldly science. The first essential knowledge must rely on what the Apostle carried, while the latter should not always be referred to the Apostle. 
Basically, the Islamic education system is based on an awareness that every Muslim is required to study and should not ignore it because of the Messenger of Allah. said: "Seeking the knowledge is obligatory (fardhu) for every person" islam "(HR Baihaqi). Many nash al-Qur'an and hadiths of the Prophet also mention the virtue of seeking knowledge and knowledgeable people. Indeed, the motivation of a Muslim to seek knowledge is a ruhiyah impulse, not to pursue the mundane worldly pursuit. A learned Muslim who is motivated by his faith, that Allah SWT loves and honors those who seek knowledge and knowledge in the world and in the hereafter.

How important is education, because with the process of education, humanity can maintain its existence as a noble human, through the empowerment of the basic potential and the gift that God has given. If all is forgotten by ignoring education, people will lose their identity.

The concept of education in Islam according to AlBughuri not only emphasizes on the teaching of intellectualoriented teaching, but rather emphasizes on the formation of intact and rounded personality. Islamic education requires the perfection of complete life according to the word of Allah in the letter of Al Baqarah verse 208, which means: "O ye who believe, enter into Islam as a whole, and do not follow the steps of the devil. The devil is a real enemy to you. "

For human education is an important effort to instill and actualize Islamic values in real life through faithful and pious Muslim personalities, in accordance with the dignity and degree of humanity as a caliph on earth. God's appreciation of knowledgeable and educated people is depicted on the following verse. "Allah will raise up the believers among you 
and those who have been given the knowledge of degrees ( $\mathrm{Al}$ Mujadalah: 11). "So ask those who have knowledge if you do not know" (An-Nahl: 43). Say: "Are those who know with those who do not know?" (Az-Zumar: 9).

The importance of education has been exemplified by God in the first revelation, the letter Al-Alaq verse 1-5 which contains many educational and teaching signals with broad and deep meaning. The behavior of the Prophet Muhammad himself, as long as his life is laden with high educational values, as the word of Allah "Verily in the Messenger of Allah is the best example for you to those who hope Allah and His coming, the Day of Judgment and he calls many of Allah "(Al Ahzab: 21).

\section{Concept of Islamic Education According to Al-Qur'an}

Referring to the information of the Qur'an education encompasses all aspects of the universe, not just limited to mere mortals, that is by placing God as the Supreme Educator. ${ }^{4}$ Broadly speaking, the conception of education in Islam is to meet the basic influence with the influence of teaching. The influence of innate and educational influences is expected to be an integrated force that processes toward the formation of a perfect personality. Therefore, education in Islam not only emphasizes the teaching oriented intellectual reasoning, but rather emphasizes the education that leads to the formation of a whole and round keribadian.

4 Muh Haris Zubaidillah, 'FILSAFAT ILMU: ONTOLOGI, EPISTEMOLOGI DAN AKSIOLOGI', h. 2, accessed 19 July 2018, https://doi.org/10.31227/osf.io/7dpk6. 
The concept of education in Islam that refers to the teachings of the Qur'an and hadith, is very clearly unraveled in the story of Luqman. Dr. M. Sayyid Ahmad Al-Musayyar menukil some verses of the Qur'an in Surat Luqman. He said there are three basic concepts of education in Islam according to the Qur'an run by Luqman to his son. As is known, Luqman is given the virtue of Allah in the form of wisdom, namely the accuracy of speech, the sharpness of reason and purity of nature. With such privileges, Luqman wants to teach his son wisdom and raise it with the method of wisdom that too.

\section{Cultivation of Faith}

The first concept of education is the laying of the foundation, the planting of the oneness of God, the straightening of the aqidah, along with his greatness and perfection. The monotheistic sentence is the main focus of his education, as Lukman said when advising his son: "O my son! Do not associate partners with Allah, actually associating Allah is really a great tyranny "(Lukman: 13). In another verse Allah says: "Then know, There is no God (worthy of worship) except Allah" (Muhammad: 19). The formation of faith on the oneness of God is the ultimate foundation, so that all the Apostles and Prophets sent to the people they convey and impart to their people are about this concept, Allah says: And We did not send an apostle before you but We revealed to him: For there is no God but me, so worship Me by you all "(Al-Anbiya ': 25). In a hadith narrated by Muslims from 'Abbas bin Abd. Muttalib ra. For he heard the Messenger of Allah. Said, "Having felt, the one who is pleased with Allah as his Lord, Islam as his religion, and Muhammad as his Messenger" (HR Muslim), so that the highest branch of faith is to believe that there is no god 
but God with all his heart. From Abu Hurairah ra. He said, The Messenger of Allah said: "Faith there are seventy branches. The most important thing is to say Laa Ilaaha illallah (There is no God but Allah), while the lowest is to get rid of the disturbance from the road. And shame is one of the branches of faith "(Muslim). There is no education without faith. There is no moral, social interaction, and ethics without faith. If faith is righteous, then straight is the aspect of life. Why? For faith is always followed by feelings of self introspection and fear of God. This is where Luqman confirms this to his son by saying, "My son, if there is any weight of the mustard seed, and in the rock or in the heavens or in the earth, Allah will bring it. Verily Allah is Being Smarter, Knowing. "(Luke: 16). A believer must believe that nothing can be hidden from God. Allah is Knowing what is in the folds of the human heart. From here he will do all his charity and his activities solely to seek Allah's approval without the attitude of riya or hypocritical, and without mentioning it or hurt others.

\section{Education Pillars}

The second concept in education according to Luqman is the pillars of education. Allah SWT tells about Lukman's advice to his next son: "O my son! Practice prayer and order (men) to do what makruf and prevent (them) from the evil and be patient with what happened to you, in fact that way including the important thing "(Lukman: 17) He ordered his son to pray, take responsibility amar ma 'ruf nahi munkar, as well as instilling a patient nature.

Prayer is the light that illuminates the life of a Muslim. This is a daily obligation of a Muslim who can not be left 
behind while still good (red mukallaf). Because the prayer is the pillar of religion (HR Abnu Nu'aim) with the correct prayer can prevent man from the abomination and malice (Al Ankabut: 45), as well as prayer as a means to always remember Allah (Thaha: 14) is a concrete form of worship performed by the servant to his Rabb, because in the prayer ritual there is a ruku 'and prostration which is a form of perfect worship and submission to God. On the importance of the prayer, the Prophet told his ummah to instruct and educate their children to establish a prayer since the age of seven, as he said: "Order the children to establish prayer when they are seven years old and ten years old. So when they reached the age of ten they strove to establish prayer "(HR Abu Dawud). It is narrated from Ali ra that the last words of Rasulullah saw are "As-Shalat, as-shalat (shalat! Shalat!)" (HR Abu Dawud) shows that prayer is very important.

Amar ma'ruf nahi munkar is a term for constructive criticism, a sense of love and a great brotherhood to one another, not intended to seek fault and ghibah. The ummah of Islam has been privileged by the duty of this ma'ruf nahi munkar by his word, "You are the best of mankind born to mankind, enjoining what is ma'ruf, and preventing the wrong, and believing in Allah. .. "(Ali Imran: 110). So when there is evil, then every one who sees it must prevent it or hate it. He (the Holy Prophet) said: Whoever among you sees a vengeance, let him change it with his hands, if he can not, then with his tongue, if he can not, then with his heart, and that is the weakest of faith ". The concept of good-by-fact nature should be embedded in the student, so he is aware of the importance and demand of this matter, also imploring them to 
convey to others all the knowledge and education they acquire is a responsibility and mandate as a believer, The Messenger of Allah (may peace be upon him) said: Say (you hear) from me though only one verse "(HR Bukhari). One of the goals of deepening knowledge is to communicate to others, as a concept of Allah swt in the Qur'an: "Why do some of them not go to deepen their religious knowledge and to warn their people when they have returned, that they may guard themselves "(At Taubah: 122), this is what Allah wants, how the ummah of ummah is the rabbis of those who teach (educate, convey) and learn (Ali Imran: 79)

Then about patience, this nature is indispensable for believers, because it will not escape exams and trials in this world, both fears, hunger, loss, etc. As Allah sets out: "And We will certainly test you with a little fear, famine, lack of wealth, soul, and fruit. And convey the glad tidings to the patient ones "(Al Baqarah: 155). Because besides the patient he will live his life with falsehood, when it gets grace, he is so proud, when it gets misfortune, he is desperate, as Allah suggests: "And if We bestow Our favor upon man, then We withdraw it, it must have been desperate and not grateful. And if We give him a misfortune, he will say: 'It has been lost from me', indeed, he is exceedingly glad and proud except the patient and the doer of good. "(Hud: 9-11) ).

Patience is diverse. There is patience over obedience until obedience is fulfilled, there is patience for disobedience until disobedience is avoided, and there is also patience over life's difficulty until it is received with a pleasant and calm feeling. A believer is in a position of gratitude and patience. In 
the facility he received, he was grateful. In every difficulty he faced, he must be patient and introspective.

\section{Social Ethics}

Allah swt said about Lukman's words to his next son: "And do not turn your faces away from men (because of arrogance) and do not walk in the earth arrogantly. Really, God does not like arrogant people and pride themselves. And simplify it in walking and softening your voice. The worst of all is the sound of a donkey "(Lukman: 18-19)

The third concept is social ethics. Luqman's education method cultivates noble noble and noble virtues. Luqman describes it for his son with the forbearance of disbelief and gratitude, and commands not to be too fast or not too slow in walking, and lowering the voice. A Muslim should be reminded not to insult and arrogant. Because, all human beings are from despicable germs and will end up being rotten carcasses. And when it comes to life, it hurts to stroke and sweat when it's hot. If he himself snapped, hurt his heart then do not snap at someone else. So with this concept will be a fair, prosperous and harmonious society. This is the glory of Islam as the Messenger of Allah said: "The most important Islam is that any other Muslim is safe from the tongue and hand" (HR Ahmad, Muslim and others)

\section{E. Conclusion}

Education is to develop the development of physical and spiritual potential encompassing the full potential of students, both psychomotoric, cognitive potential, and their affective potential for the realization of human beings who 
have the main personality in terms of religion is Insan Kamil and to be a servant of Allah SWT who always close to Him.

For human education is an important effort to instill and actualize Islamic values in real life through faithful and pious Muslims who, according to the dignity and degree of humanity as a caliph on earth.

The concept of education in Islam which refers to the teachings of the Qur'an, there are three basic concepts: cultivation of faith and aqidah, educational pillars and social ethics as revealed from Lukman's advice to his son.

Al-Qur'an and Al-Hadtis have offered the conceptualization of education, which is based on naqliyah science that underlies all aqliyah science, so it is hoped that educators can integrate between reason and revelation, syar'iyyah sciences and the sciences of ghairu syar'iyyah in education process. Thus, through this effort educators can realize the process of humanizing human beings as an educational destination, namely teaching, nurturing, training, directing, building and developing the full potential of learners in order to prepare them to realize their function and humanitarian leaflet in the presence of Allah SWT, SWT and conduct the mission of the Caliphate on earth, as a creature who seeks to pursue ilahiyah values by prospering life in the order of life together with peace, peace and prosperity.

\section{REFERENCES}

Zubaidillah, Muh Haris. 'EPISTEMOLOGICAL VIEWS OF ISLAMIC EDUCATION PHILOSOPHY AS A ISLAMIC EDUCATION BASIS.' Al Qalam: Jurnal Ilmiah Keagamaan Dan Kemasyarakatan 1, no. 1 (2018): 1-12. 
-. 'FILSAFAT ILMU: ONTOLOGI, EPISTEMOLOGI DAN AKSIOLOGI'. Accessed 19 July 2018. https://doi.org/10.31227/osf.io/7dpk6. . 'HAQIQAH DAN MAJAZ DALAM ALQURAN'. Accessed July 2018. https://doi.org/10.31227/osf.io/fzatu.

-. 'NILAI-NILAI PENDIDIKAN ADVERSITY QUOTIENT PADA CERITA NABI MÛSÂ DALAM ALQURAN'. Al Qalam: Jurnal Ilmiah Keagamaan Dan Kemasyarakatan 11, no. 24 (2017). 